\title{
Deliberate HIV exposure by 6 African-American youths was rooted in growing up poor in the inner city
}

\author{
Tourigny SC. Some new dying trick: African American youths “choosing”HIV/AIDS. Qual Health Res 1998 Mar;8:149-67.
}

\section{Question}

What are the experiences of 6 African-American youths who deliberately sought exposure to HIV?

\section{Design}

Ethnography.

\section{Setting}

Inner city Detroit, Michigan, USA.

\section{Participants}

6 African-American youths (4 women, 2 men) ranging in age from 12-22 years who had $\geqslant 1$ family member with HIV/AIDS and who had deliberately sought exposure to HIV. All respondents were HIV seropositive.

\section{Methods}

Respondents told their stories during meetings that took place over time at locations chosen by the respondents. Meetings often occurred in the respondents' homes.

\section{Main results}

The decisions of the 6 youths to deliberately expose themselves to HIV were presented in the context of "marginalization, insensitive social policies, and demanding caretaking responsibilities" inherent in growing up poor in the inner city. The following are excerpts of conversations about why the respondents deliberately sought exposure to HIV:

Belinda: (mother with AIDS and 2 HIV positive stepsisters) “... the easiest thing to do was to just give up and get sick too ... maybe now I'se sick, I'll be maybe able to get the things I needed before ... the counselling and the assistance and the money I'se asked for all these times and nobody could get me ... I never existed for them before; now, they have to count me ..."

Brendon: (sister and nephew with AIDS) "Everybody was ragging me about not getting nowhere, not getting no job ... Well, there ain't nothing to do here. I looked around at my sister and she got everybody seeing to her hand and foot... This AIDS things don't need make you sick at all, but people sure listen up when you talk ... She's getting good money from the feds ... She ain't got no need to worry ever again about nothing ... Two of my homies gone died last month, from gunshot wounds ... I ain't gonna live no 15 years anyway ... with no jobs out here, I can't get me no real family, no kids, nothing ... these "hopes" we'se supposed to have, that's crap. Ain't worth the fight!"
Azure: (mother with AIDS and brother HIV infected at birth) "It was worth it, to have my baby. My mother always said she loved my baby brother all the more, 'cause she was sick and he was sick ... It's human nature for people to have babies, to be born, to die. So when they say "safe sex," they mean no babies. That's sad ... There ain't much goin' on for Black girls like me. My mom tried hard, and she said there ain't much we could do with no school ... [the government] gonna pay for everything like they done for my mom."

Luen: (mother with AIDS) "I felt he [my HIV positive boyfriend] deserved to have someone with him ... and I know I am destined to love and lose and I don't want that anymore ... I made the choice not to be left anymore ... We don't need to worry about the future, we can enjoy the day, because there is no future to think about."

Chuckie-Dog: (HIV positive brother) [AIDS is] "A white virus manufactured by White people to kill us off ... First they import drugs into the 'hood, then, when we ain't dying fast enough, this HIV ... now I can really get in people's faces about how they invented a virus to make Black folk completely dependent on them ... if you got AIDS, you get more [government aid] ... I knew what I was doing, ... If I can end up doing some activism, I need to be on the inside."

SueAnn: (HIV positive father) "I don't know if they'll [gang] let me hang out much longer without jumping in." SueAnn felt challenged to prove herself and did-"I had to boot with someone else's mix ... they brought a syringe with blood and coke... I never really thought about HIV, although four of the guys got it and I knew their blood would be in the mix."

\section{Conclusions}

The stories of 6 youths who deliberately sought HIV exposure were rooted in the social inequalities of inner city life. They were overwhelmed by worry, fear, depression, caregiving, and hopelessness and robbed of their childhood by poverty. They were all young and deeply involved with their loved ones, such that leaving was not an alternative. With no obvious recourse or avenues of success, AIDS offered a way of accessing care. It also provided "self erasure ... without the immediacy of death."

Source of funding: not stated.

For correspondence: no current address available.

\section{Commentary}

The stories presented by Tourigny provide a glimpse of the reality of how 6 individuals made health choices based on the context of their lives. For these individuals, becoming HIV positive offered a potential improvement in their quality of life. Qualitative study findings such as these afford an opportunity for healthcare providers to reflect on how their view of reality may differ from others and the implications for their professional practice. ${ }^{1}$

Nurses are uniquely positioned to gain understanding about quality of life issues from the perspective of the individual. Through respectfully working with others, nurses gain knowledge about personal and structural influences on health. $^{2}$

This study shows the impact of inequitable social conditions on the health of disenfranchised people. It provides direction for nursing practice focused on individuals and on the development of public policy. Nurses are knowledgeable about the functioning of economic and social policy and its effect on health. We must use this knowledge to advocate for the development of public policy that promotes and supports health for all. ${ }^{2}$

$$
\begin{array}{r}
\text { Penny Nelligan, RN, BScN } \\
\text { Programme Manager } \\
\text { Hamilton-Wentworth } \\
\text { Regional Public Health Department } \\
\text { Hamilton, Ontario, Canada }
\end{array}
$$

1 Mitchell GJ. Nurs Sci Q 1996;9:143-4. 2 Labonte R. Health Educ Q 1994;21:253-68. 